\title{
Implementation of MPPT Algorithm for Single-Stage Grid- Connected Photovoltaic System Using Incremental Conductance Method
}

\author{
Mustafa Abu-Zaher ${ }^{1}$, Yousry Atia ${ }^{2}$, Farag K . Abo Elyousr ${ }^{3}$, Emad H. El-Zohri ${ }^{1}$ \\ ${ }^{1}$ Electrical Dept, Faculty of Industrial Education, Sohag University, Egypt. \\ 2 Electronics Research Institute, Giza, Egypt. \\ ${ }^{3}$ Electrical Engineering Dept, Faculty of Engineering, Assiut University, Egypt. \\ mostafa.abuzaher@yahoo.com
}

\begin{abstract}
This paper presents simulation and implementation of maximum power point tracking algortim for single stage three-phase grid-connected PV system by using incremental conductance method.The maximum efficiency is realized when PV works at its maximum power point, which is contingent on irradiation and temperature. Since the irradiation and temperature always change with time, a PV system which is able to track the maximum power point needs to be established to produce more energy. The INC method shows a superior performance, lower oscillation and it took three seconds to match MPP best time to give stability to the system. The control strategy is supported out using MATLAB/Simulink and experimentally validated with a dSPACE MicroLabBox controller.
\end{abstract}

Keywords - Photovoltaic, Maximum power point tracking, Single-stage, Grid-connected,Incremental conductance.

\section{INTRODUCTION}

In the present development, rapid innovation with advance technology has enlarged the demand for modern resourses of electric power [1]. Installation of additional power sources pose challenges due to the exhaustion of conventional fossil fuels in addition to environmental pollution and global roasting. This necessitated the exploitation of renewable sources of energy, such as identical solar and wind energy by carefully accommodating their seasonal variations [2]. Wide spread custom of renewable energy sources in dispersed power generation and a great saturation level is expected in the near future. PV generators are exclusively becoming increasingly popular to supply remote loads [3] and grid connected schemes. There are two events for photovoltaic systems: 1) standalone systems and 2) gridconnected systems. Standalone systems are used in low-power application and use many battery banks for power registration [4]. Grid-connected applications are used for low and high power applications to feed the utility grid with renewable energy [5]. PV power is converted to $A C$ and directly injected into utility grid. Grid-connected systems may be single-stage or two-stage systems as shown in Fig. 1. In two-stage systems, the first stage is a dc-dc boost converter for boosting the PV voltage and realizing MPPT, where the second stage is a DC-AC inverter that synchronizes the injected power with the utility grid power and transfers the collected power from the PV array to the AC grid [6]. However, two-stage systems have drawbacks, such as lower reliability, complication in control, larger size, higher cost, more power loss and lower efficiency. On the other hand, single-stage grid-connected systems offerd many advantages such as more efficiency, simple topology and economical than the two-stage system [7]. For PV systems, the PV power-voltage and voltage-current curves have a non-linear relationship. To maximize the output power from the PV system and to maximize its efficiency, it is indispensable to operate it at the maximum power point (MPP). MPPs are dependent on environmental variables such as sun insolation and module surface temperature. So that to achieve operation at MPP while conditioning the output power in harmony with the power grid is considered a large significant task in such systems. MPP position changes in with changes of weather conditions [8]. Many MPPT techniques have been developed such as perturb and observe method [9] and the incremental conductance method [10]. MPPT algorithm is done and controlled by many controllers as fuzzy logic controller [11] and neural network controller [12]. With a goal to match MPPT, this paper presents an implementation and expermental results to have it from PV as well as to increase the efficieny 
and performance of a single stage three-phase system connected to grid, where incremental conductance algorithm used in that this research. In the incremental conductance method, the controller must measure the incremental changes in array current and voltage to predict the effect of a voltage change. This method requires more computation in the controller, but it can track changing conditions more rapidly than the perturb and observe method (P\&O) [13]. Like the $P \& O$ algorithm, it can produce oscillations in the power output. This method utilizes the incremental conductance $(\mathrm{d} / / \mathrm{dV})$ of the photovoltaic array to compute the sign of the change in power with respect to voltage $(\mathrm{dP} / \mathrm{dV})$. The inverter model and control algorithm of MPPT are developed and simulated in the Matlab/Simulink SimPowerSystem blockset environment and then linked to the prototype inverter by utilyzing the dSPACE MicroLabBox controller board. This paper is organized as follows: section 2 describes the

system description; section 3 presents the mathematical model of PV; section 4 describes the control system of three-phase Grid-Connected PV System; section 5 shows the simulation followed by the corresponding discussion; section 6 shows the expermintal results; and finally, the conclusions are given in section 7 .
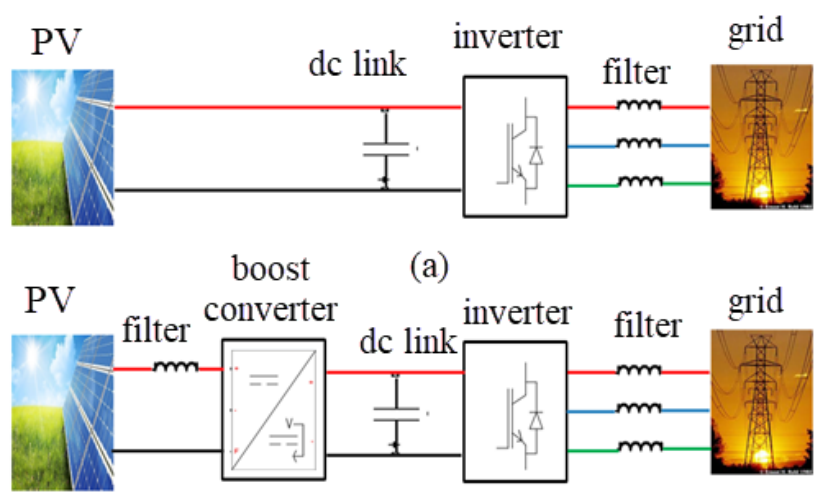

(b)

Fig .1. PV grid tied classification according to number of stages (a) single stage system (b) two stages system

\section{SYSTEM DESCRIPTION}

Single-stage structure is used to remove the $D C / D C$ converter, increase the efficiency, and reduce the overall system cost. Fig. 2 shows the block diagram of the suggested system. The system contains PV arrays, DC link capacitor, a three- phase voltage source inverter, three- phase inductance, threephase step up transformer and utilty grid. Three control loops are implemented concerning MPPT controller, voltage control loop and current control loop.

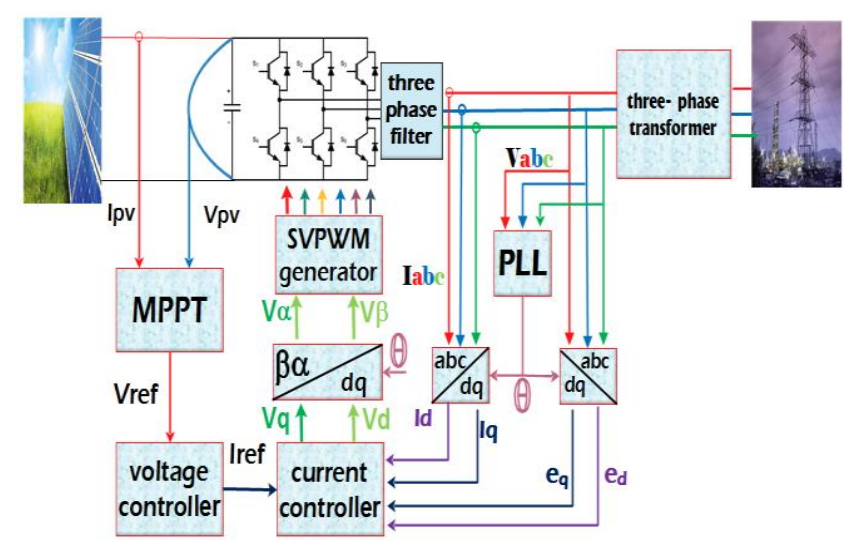

Fig .2. Block graph of single stage three -phase inverter

\section{Photovoltaic generator Model}

Fig. 3 shows equivalent circuit of one photovoltaic array [14]. Features of PV system is described as follows:

$$
I_{P V}=I_{d}+I_{R P}+1
$$

$I=I_{P V}-I_{O}\left[\exp \left(\frac{V+R_{s} I}{V_{t h} n}\right)-1\right]-\frac{V+R_{s} I}{R_{p}}$

$V_{t h}=\frac{N_{s} K T}{q}$

$I_{O}=I_{o, n}\left(\frac{T_{n}}{T}\right)^{3} \exp \left[\frac{q^{*} E_{g}}{n^{*} K}\left(\frac{1}{T_{n}}-\frac{1}{T}\right)\right]$

Where,

I: the output current.

$\mathrm{V}$ : the output voltage.

Ipv:is the generated current under a given insolation.

$I_{d}$ : diode current.

$I_{\mathrm{RP}}$ : the shunt leakage current.

10: the diode reverse saturation current.

$\mathrm{N}$ : the ideality factor (1.36) for a p-n junction.

$R_{s}$ : the series loss resistance $(.1 \Omega)$.

$\mathrm{RP}_{\mathrm{P}}$ : the shunt loss resistance (161.34 $\Omega$ ).

$V_{\text {th: }}$ : the thermal voltage.

Q: the electron charge $\left(1.60217646 \times 10^{-19} \mathrm{C}\right)$.

$\mathrm{K}$ :the Boltzmann constant $\left(1.3806503 \times 10^{-23} \mathrm{~J} / \mathrm{K}\right)$.

$\mathrm{T}$ : ( in Kelvin) is the temperature of the $\mathrm{p}-\mathrm{n}$ junction.

$E_{g}$ : the band gap energy of the semiconductor $(E g \approx$ 
$1.1 \mathrm{eV}$ for the polycrystalline $\mathrm{Si}$ at $\left.25^{\circ} \mathrm{C}\right)$.

$\mathrm{I}_{0, \mathrm{n}}$ : the nominal saturation current.

$\mathrm{T}$ : the cell temperature.

$T_{n}$ : is cell temperature at reference conditions.

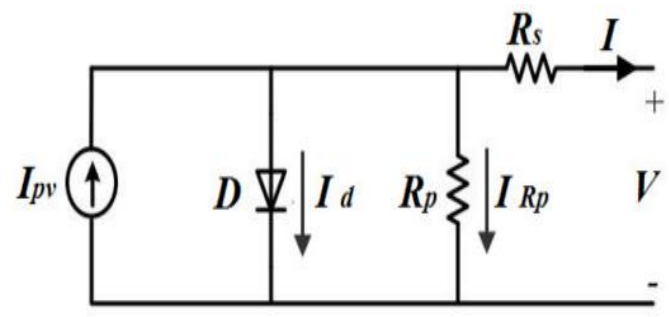

Fig. 3. Equivalent circuit of photovoltaic array

The following electrical characteristics of PV modules that were used are shown in Table 1, the array specifications at $1000 \mathrm{w} / \mathrm{m}^{2}-25^{\circ} \mathrm{C}$ are shown in Table 2. The attendant power - voltage $(P-V)$ characteristics under changing climatic conditions (temperature and radiation) are shown in Figs. $4 \mathrm{a}$ and $4 \mathrm{~b}$

Table 1. Electrical Specifications for the Solar Module Trina Solar TSM (295)

\begin{tabular}{|c|c|c|}
\hline Parameter & Sympol & Value \\
\hline Maximum Power & $\mathrm{Pm}$ & $295 \mathrm{~W}$ \\
\hline Short circuit current & Isc & $8.6 \mathrm{~A}$ \\
\hline Open circuit voltage & Voc & $45 \mathrm{~V}$ \\
\hline Maximum power voltage & $\mathrm{Vmp}$ & $36.5 \mathrm{~V}$ \\
\hline Maximum power current & $\mathrm{Imp}$ & $8.08 \mathrm{~A}$ \\
\hline Number of parallel cell & $\mathrm{Np}$ & 1 \\
\hline Number of series cells & $\mathrm{Ns}$ & 72 \\
\hline
\end{tabular}

Table 2 Array Specifications

\begin{tabular}{|c|c|c|}
\hline Parameter & Symbol & Value \\
\hline Total peak power & Ptm & $2655 \mathrm{~W}$ \\
\hline Number of PV panels & $\mathrm{N}$ & 9 \\
\hline Voltage input & $\mathrm{Vm}$ & $360 \mathrm{~V}$ \\
\hline
\end{tabular}

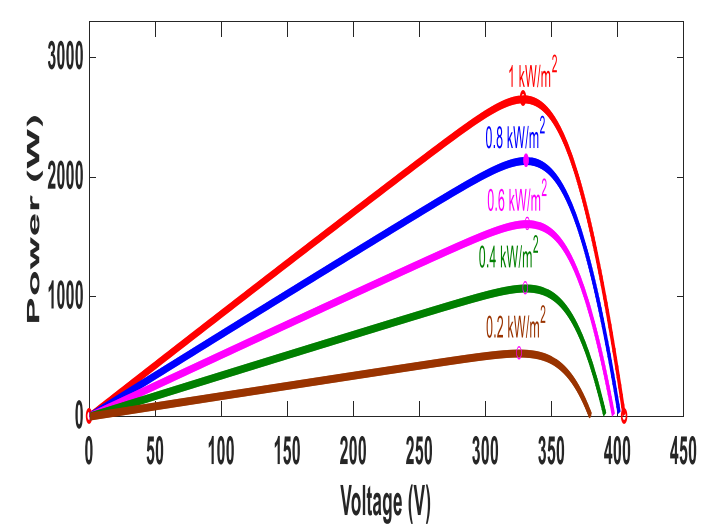

Fig. 4.a $\mathrm{P}-\mathrm{V}$ characteristics of $\mathrm{PV}$ generator at varying radiation

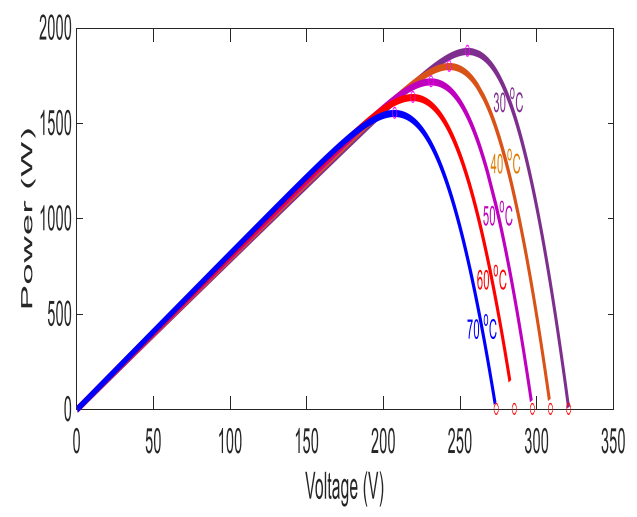

Fig. 4b P-V characteristics of PV generator at varying temperature

\section{Mathematical Model of Three-phase Grid- Connected Inverter}

The circuit topology of the grid-connected voltage source inverter (VSI) is shown in Fig. 5.

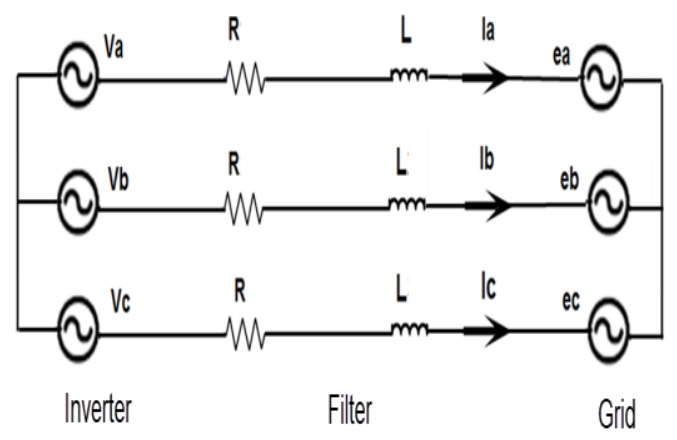

Fig. 5. Model of three- phase grid connected inverter

The assumption of symmetrical and balanced state of the grid voltage and zero grid impedance are presented; therefore, it can be expressed as,

$$
\left[\begin{array}{l}
e a \\
e b \\
e c
\end{array}\right]=\left[\begin{array}{c}
V_{m} \sin \omega \mathrm{t} \\
V_{m} \sin \left(\omega \mathrm{t}-\frac{2 \pi}{3}\right) \\
V_{m} \sin \left(\omega \mathrm{t}+\frac{2 \pi}{3}\right)
\end{array}\right]
$$

The relation between VSI output voltages and line currents in the stationary reference frame is as follows: 


$$
\left[\begin{array}{l}
e a \\
e b \\
e c
\end{array}\right]=\left[\begin{array}{c}
V_{a} \\
V_{b} \\
V_{c}
\end{array}\right]-R\left[\begin{array}{c}
I_{a} \\
I_{b} \\
I c
\end{array}\right]-L \frac{d}{d t}\left[\begin{array}{c}
I_{a} \\
I_{b} \\
I c
\end{array}\right]
$$

The stationary reference frame can be transformed into the dq rotating reference frame using parks transformation as: [14]

$\left[\begin{array}{l}e d \\ e q\end{array}\right]=\left[\begin{array}{l}V d \\ V q\end{array}\right]-L \frac{d}{d t}\left[\begin{array}{l}I d \\ I q\end{array}\right]+\omega L\left[\begin{array}{c}-I d \\ I q\end{array}\right]-R\left[\begin{array}{c}I d \\ I q\end{array}\right]$

Equation (7) can be communicated in the state space form as: [16]

$$
\frac{d x}{d t}=A \cdot \mathrm{X}+\mathrm{B} \cdot \mathrm{U}
$$

Where the state vector $[X]$, the input vector $[U]$, the state matrix $[A]$, and the input matrix $[B]$ are defined as follows:

$$
\begin{aligned}
& x=\left[\begin{array}{c}
I d \\
I q
\end{array}\right], \quad U=\left[\begin{array}{llll}
V_{d} & V_{q} & e_{d} & e_{q}
\end{array}\right]^{T} \\
& A=\left[\begin{array}{rr}
-\frac{R}{L} & \omega \\
-\omega & -\frac{R}{L}
\end{array}\right], \quad B=\left[\begin{array}{ccc}
-\frac{1}{L} & 0 & 0 \\
0 & -\frac{1}{L} & \frac{1}{L}
\end{array}\right]
\end{aligned}
$$

The advantages of operation in $d-q$ synchronous reference frame is to deliver a method to control the active and reactive power independently. The active and reactive power are given by:

$$
\begin{aligned}
& P_{d}=\frac{3}{2}\left(\mathrm{~V}_{d} \mathrm{I}_{d}+\mathrm{V}_{q} \mathrm{I}_{q}\right) \\
& P_{q}=\frac{3}{2}\left(\mathrm{~V}_{q} \mathrm{I}_{d}-\mathrm{V}_{d} \mathrm{I}_{q}\right)
\end{aligned}
$$

\section{MPPT Control Algorithms}

\section{Incremental-conductance (INC) method}

is found on the circumstance that the slope of the PV array power curve against voltage is zero at the MPP. The MPPT algorithm, which uses the INC method usually and has a fixed iteration step size determined by the INC, tries to develop the tracking time and to produce more energy on a vast irradiation changes environment. The MPP can be calculated by using the relative between $\mathrm{dl} / \mathrm{dV}$ and $\mathrm{I} / \mathrm{V}$. If $\mathrm{dP} / \mathrm{dV}$ that is negative, then the MPPT is located on the right side of the current position and if it is positive, the MPPT is on left side [17]. The equation of INC method is:

$$
\begin{aligned}
& \frac{d p}{d v}=\frac{d(\mathrm{v} . \mathrm{I})}{d V}=I \frac{d V}{d V}+V \frac{d I}{d V} \\
& \frac{d p}{d v}=I+V \frac{d I}{d V}
\end{aligned}
$$

MPP is reached when $\mathrm{dP} / \mathrm{dV}=0$ and

$\frac{d I}{d V}=-\frac{I}{V}$

$\frac{d P}{d V}>0$ then $V_{P}<V_{m p p}$

$\frac{d P}{d V}=0$ then $V_{P}=V_{m p p}$

$\frac{d P}{d V}<0$ then $V_{P}>V_{m p p}$

If the maximum power point (MPP) during operation lies on the right side, $\mathrm{dl} / \mathrm{dV}<-\mathrm{I} / \mathrm{V}$ and then the $\mathrm{PV}$ voltage must be decreased to reach the MPP [17]. INC method can be used to determine the MPP, improve the PV efficiency, and decrease power loss and system cost. INC algorithm can be seen in Fig. 6.

The oscillation around MPP area can also be suppressed in trade of with its implementation complexity. 


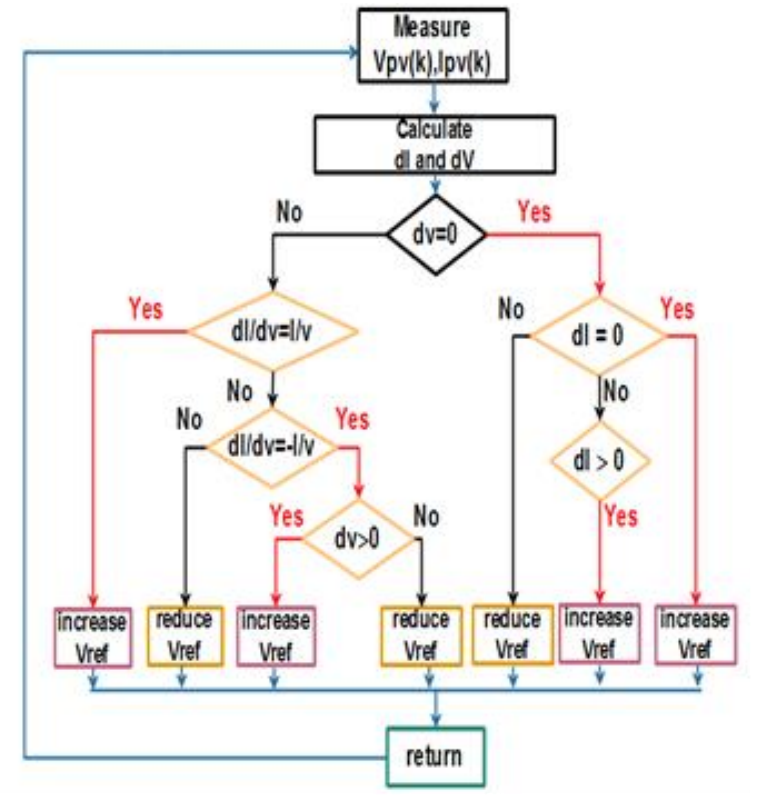

Fig.6. Flow chart of MPPT algorithm

\section{Control of DC Link Voltage}

DC link voltage is controlled via the voltage controller block as shown in Fig. 2. The controller regulates the dc-link capacitor voltage according to the reference voltage $\left(\mathrm{vdc}_{\text {ref }}=\mathrm{VPV} \mathrm{V}_{\text {ref }}\right)$, decided by the MPPT scheme. The dc-link voltage regulation is achieved through the control of direct axis current, which in consequence, controls the real power injection into the grid. The main advantage of the single-stage construction is the operation at a variable dc-link voltage. The dc-link voltage has to track the PV array's MPP, which is controlled by the MPPT algorithm out of changing the dc-link reference voltage [18]. The estimated dc-link voltage reference (Vref) is processed through a voltage limiter and feeds a PI controller to establish a current command (current controller). Alternatively, the dc link voltage controller may be achieved by regulating the energy flow in and out of the dc-link capacitor.

\section{Current Controller}

MPPT algorithm for single-stage system is based on dc-link control capability of the inverter. Voltage control loop outs d-axis reference current (ld-ref) that is used as reference current to the current controller. By controlling the Id, the active power injected to the grid can be controlled, whereas the q-axis reference is set to zero for unity power factor operation [19]. In this paper, PI current controller is used due to its inherent simplicity as it gives good results.

\section{SIMULATION AND EXPERIMENTAL RESULTS}

\section{Simulation Results}

To investigate the performance of the proposed schemes using the INC method, a simulation model is developed for the overall system in Matlab/Simulink. The parameters of the simulated model are as follows: the output filter inductance is $5 \mathrm{mH}$ per phase, the line resistance is $0.01 \Omega$, switching frequency is $10 \mathrm{kHz}$, nominal grid frequency is $50 \mathrm{~Hz}$, dc-link capacitance value is 3300 $\mu \mathrm{F}$, and the three phase peak line voltage of the grid is $156 \mathrm{~V}$. Fig. 7 shows the theoretical results of the MPPT algorithm, where the PV voltage, current and input power are illustrated in the figure. In this figure, the starting point is at the open circuit of the PV string, where the voltage is maximum, the current is zero and the power is zero. Application of the algorithm pushs the system towards maximum power where the voltage is reduced to $\mathrm{Vmp}$, the current is increased, and the power reaches its maximum value corresponding to the environmintal condition. That value of maximum power is 1000 watt depending on irradiance $\left(600 \mathrm{w} / \mathrm{m}^{2}\right)$ and temperature $\left(35^{\circ} \mathrm{c}\right)$. Fig. 8 shows the corresponding 3-phase injected current to the grid. The current waveforms are pure sinewave and free of fluctuations which means stability of the proposed controller.
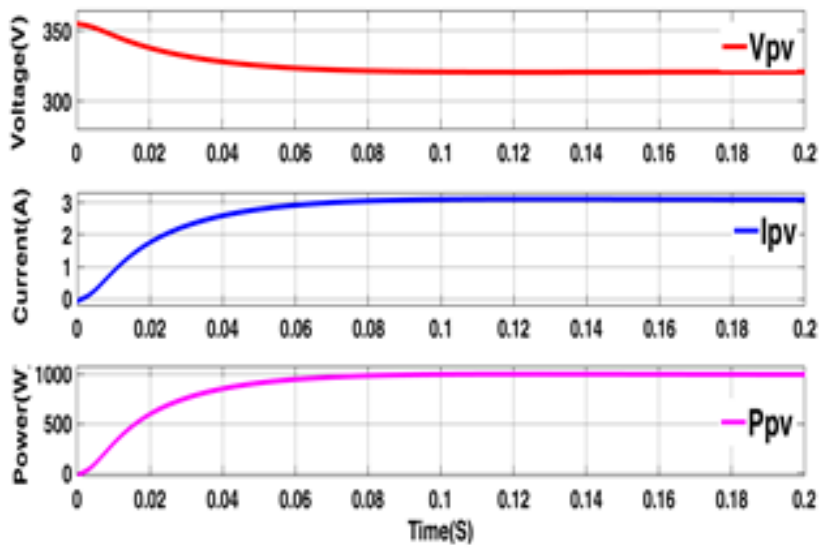

Fig.7 .Vpv, Ipv, Ppv waveforms during tracking. 


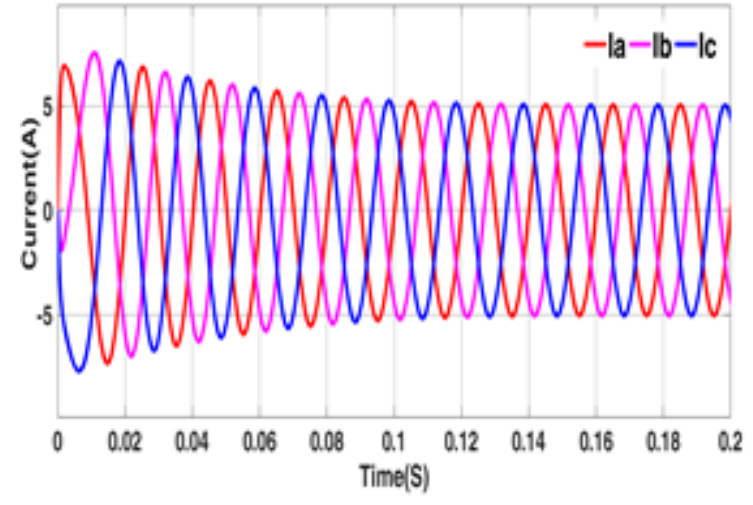

Fig. 8. 3-phase AC current injected to the grid.

\section{Experimental Laboratory}

The developed MPPT controller is designed and implemented using dSPACE MicroLabBox controller. Fig. 9 shows the experimental setup circuit that consists of PV array, step up transformer, threephase inverter, dspace MicroLabBox, card of voltage and current sensor and filter by using solar irradiance and solar temperature instruments whose values are $\left(600 \mathrm{w} / \mathrm{m}^{2}\right.$ and $\left.35^{\circ} \mathrm{c}\right)$.

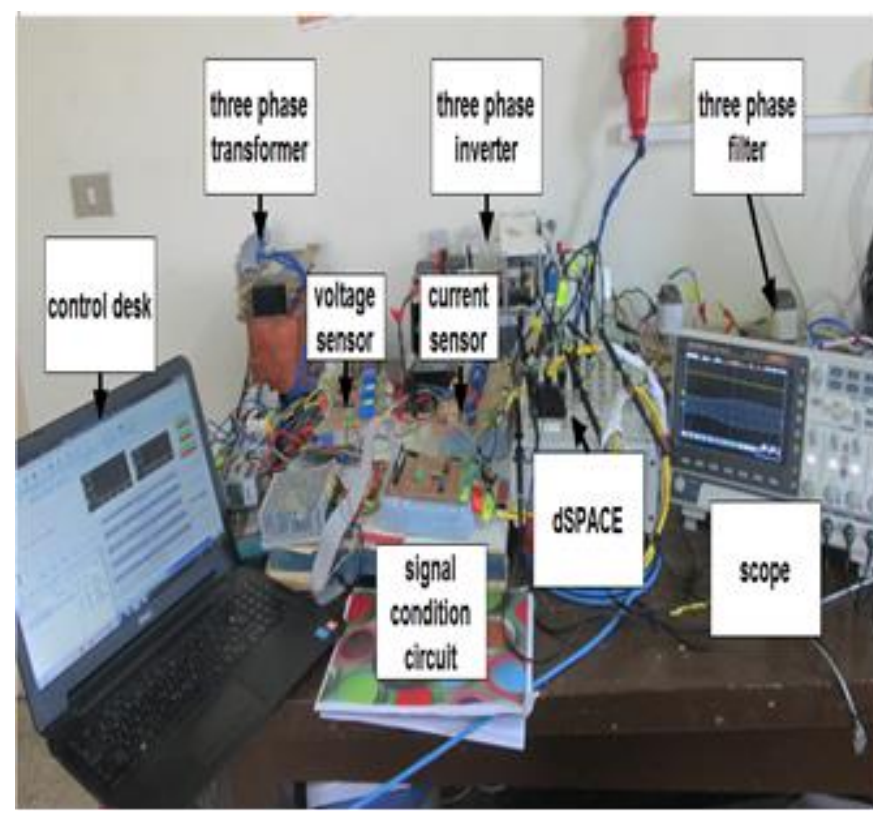

Fig.9. Expermental setup circuit

\section{Experimental Results}

Fig. 10 shows the experimental results of MPPT algorithms applied to the proposed system. The figure shows the PV voltage, current and PV output power, where the voltage of the PV decreases from open circuit $(360 \mathrm{~V})$ and reaches the MPP value
(320V), the output current increases from (0A) to (2.2A), and the output power increases to (1000 watt) maximum power point. The system moving towards the maximum power steady without oscillation or fluctuation and it matches the MPP at 3 seconds. Fig. 11 illustrates the expermental results of three phase current injected to grid by MPPT algorithm. The simulation and experimental results indicated that the system can achieve MPPT by sensing voltage and current of PV that is the input of MPPT algorthim. This figure also proves the stability of the output current and power from the system and illustrates the stability of the controller applied to the proposed system.

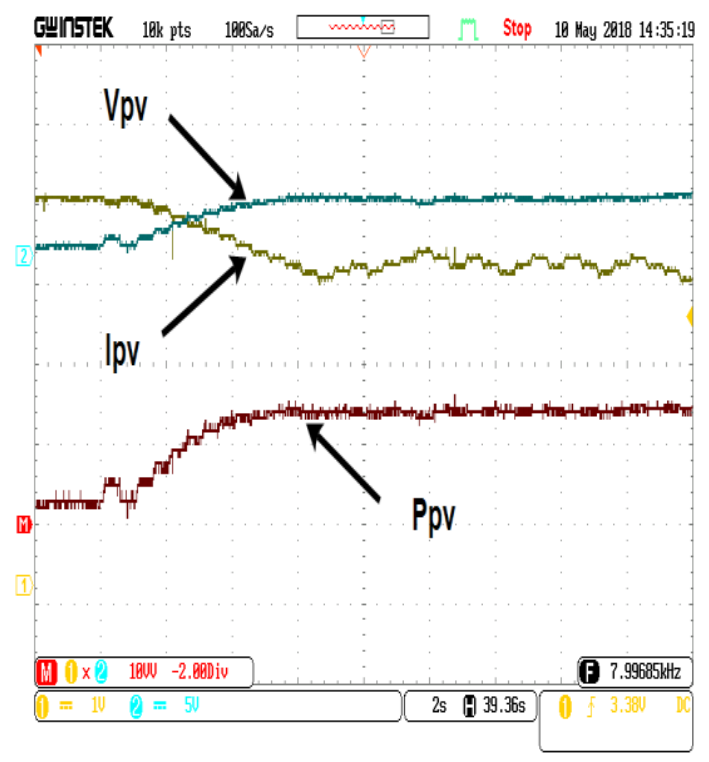

Fig. 10 .PV voltage, current, and input power [70V/div, 5A/div, $700 \mathrm{~W} / \mathrm{div}, 2 \mathrm{~s} / \mathrm{div}$.

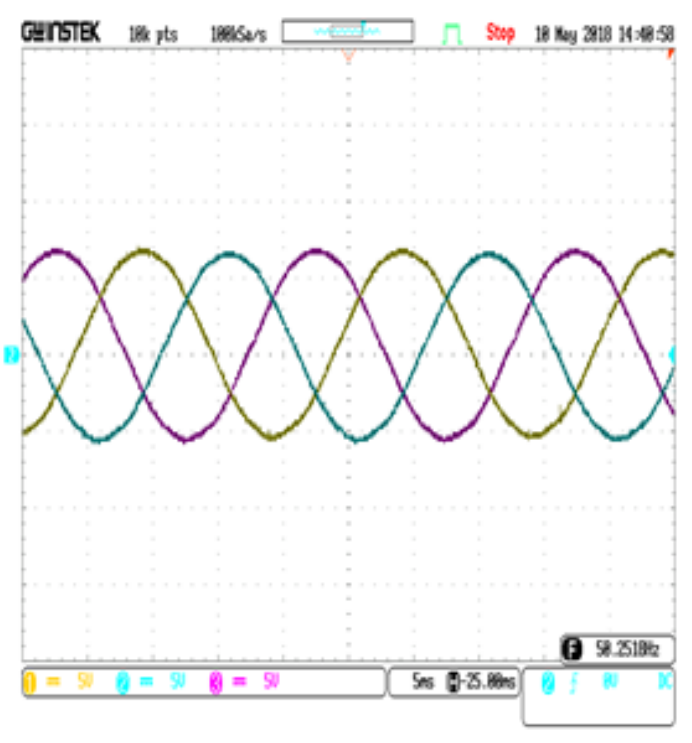

Fig. 11. three phase current injected to the grid [5A/div, $5 \mathrm{~ms} / \mathrm{div}]$ 


\section{CONCULSION}

Implementation of single stage three phase grid connected PV system is presented in this paper. In order to check the theoretical results, an experimental prototype was built. The developed MPPT algorithm was validated through the experimental results, Based on the simulated and the experimental results, the developed algorithm can track the PV MPP with a high degree of accuracy and stability, it can reach the MPPT at 3 seconds. Due to the simplicity and the low cost productivity of the developed algorithm, it is attractive for single-stage three phase grid connected PV systems.

\section{REFERENCES}

[1] M. Bilgili, A. Ozbek, B. Sahin and A. Kahraman. "An overview of renewable electric power capacity and progress in new technologies in the world." Renewable and Sustainable Energy Reviews, vol. 49, 2015, pp 323-334..

[2] A. Buonomano, F. Calise, M. D. d'Accadia and M. Vicidomini. "A hybrid renewable system based on wind and solar energy coupled with an electrical storage: Dynamic simulation and economic assessment." Energy, vol. 155, pp.174-189, 2018, doi.org/10.1016/j.energy.2018.05.006.

[3] A. Ba, E. Aroudam, O. E. Chighali, O. Hamdoun and M.L. Mohameda. "Performance optimization of the PV pumping system. "Procedia Manufacturing, vol. 22, pp. 788-795, 2018, doi.org/10.1016/j.promfg.2018.03.112.

[4] L.W. Chong, Y.W. Wong, R.K. Rajkumar and D. Isa. "Modelling and simulation of standalone PV systems with battery-supercapacitor hybrid energy storage system for a rural household." Energy Procedia, vol. 107, pp. 232-236, 2017, doi.org/10.1016/j.egypro.2016.12.135.

[5] R. Hasan, S. Mekhilef, M. Seyedmahmoudian and B. Horan. "Grid-connected isolated PV microinverters: A review." Renewable and Sustainable Energy Reviews, vol. 67, pp. 10651080, 2017, doi.org/10.1016/j.rser.2016.09.082.

[6] P. Li, W. Gu, L. Wang, B. Xu and W. Shen. "Dynamic equivalent modeling of two-staged photovoltaic power station clusters based on dynamic affinity propagation clustering algorithm."
International Journal of Electrical Power \& Energy Systems, vol. 95, pp. 463-475, 2018, doi.org/10.1016/j.ijepes.2017.08.038.

[7] O.M. Arafa, A.A. Mansour, K.S. Sakkoury, Y.A. Atia and M.M. Salem. "Realization of single-phase single-stage grid-connected PV system. "Journal of Electrical Systems and Information Technology, vol. 4, Issue 1, pp.1-9, 2017, doi.org/10.1016/j.jesit.2016.08.004.

[8] M. A.M. Ramlia, E. Prasetyono, R.W. Wicaksana, N.A. Windarko, K. Sedraoui and Y.A. Al-Turki. "On the investigation of photovoltaic output power reduction due to dust accumulation and weather conditions. " Renewable Energy, vol. 99, pp. 836844, 2016, doi.org/10.1016/j.renene.2016.07.063.

[9] J. Ahmed and Z. Salam. "An improved perturb and observe (P\&O) maximum power point tracking (MPPT) algorithm for higher efficiency." Applied Energy, vol. 150, pp. 97-108, 2015, doi.org/10.1016/j.apenergy.2015.04.006.

[10]A. Loukriz, M. Haddadi, S. Messalti. "Simulation and experimental design of a new advanced variable step size incremental conductance MPPT algorithm for PV systems." ISA Transactions, vol. 62, pp. 30-38, 2016, doi.org/10.1016/j.isatra.2015.08.006.

[11] Y-T. Chen, Y.-C. Jhang and R-H. Liang. "A fuzzylogic based auto-scaling variable step-size MPPT method for PV systems ." Solar Energy, vol. 126, pp. 53-63, 2016, doi.org/10.1016/j.solener.2016.01.007.

[12] H. Boumaaraf, A. Talha and O. Bouhali "A threephase NPC grid-connected inverter for photovoltaic applications using neural network MPPT." Renewable and Sustainable Energy Reviews, vol. 49, pp. 1171-1179, 2015, doi.org/10.1016/j.rser.2015.04.066.

[13]E.S Sreeraj, K. Chatterjee, and S. Bandyopadhyay. "One-cycle-controlled single-stage single-phase voltage-sensorless grid-connected PV system" IEEE Transactions On Industrial Electronics, vol. 60, no. 3, pp.1216-1224 March 2013. 
[14]J.A. Ramos-Hernanz, J.J. Campayo, J. Larranaga, E. Zulueta, O. Barambones, J. Motrico, U.F. Gamiz, I. Zamora. "Two photovoltaic cell simulation models in Matlab/Simulink." International Journal on Technical and Physical Problems of Engineering (IJTPE), vol. 4, no. 1, Issue. 10, pp.45-51, 2012.

[15] S.A. Lakshmanan, A. Jain and B.S. Rajpourhit. "A novel current controlled technique with feed forward DC voltage regulator for grid connected solar PV system," Power Systems Conference (NPSC), 2014 Eighteenth National.

[16] L.P. Sampaio, M.A.G. de Brito, G. de A. e Melo and C.A. Canesin. "Grid-tie three-phase inverter with active power injection and reactive power compensation." Renewable Energy, vol. 85, pp. 854-864, 2016.
[17] R.I. Putri, S. Wibowo and M. Rifa'i, "Maximum power point tracking for photovoltaic using incremental conductance method," Energy Procedia, vol. 68, pp. 22-30, 2015.

[18]W.J. Praiselin and J.B. Edward."Voltage profile improvement of solar PV grid - connected inverter with micro grid operation using PI controller," Energy Procedia, vol. 117, pp. 104-111, 2017, doi.org/10.1016/j.egypro.2017.05.112.

[19] P.M. Almeida, P.G. Barbosa, J.G. Oliveira, J.L. Duarte and P.F. Ribeiro. "Digital proportional multi-resonant current controller for improving grid-connected photovoltaic systems." Renewable Energy, vol. 76, pp. 662-669, 2015, doi.org/10.1016/j.renene.2014.11.087. 